\title{
ANALYSES OF THE FACTORS INFLUENCING SANDSTONE THERMAL CONDUCTIVITY
}

\author{
Qiang SUN ${ }^{1)}$ *, Shen-en CHEN ${ }^{2)}$, Qiao GAO ${ }^{3)}$, Weiqiang ZHANG ${ }^{1)}$, \\ Jishi GENG ${ }^{1)}$ and Yuliang ZHANG ${ }^{1)}$

\begin{abstract}
1) School of Resources and Geosciences, China University of Mining and Technology, Xuzhou, Jiangsu Province 221116, P.R.China
${ }^{2)}$ Department of Civil and Enviromental Engineering, University of North Carolina at Charlotte, Charoltte, NC 28223, USA

${ }^{3)}$ Mewbourne School of Petroleum and Geological Engineering, The University of Oklahoma, Norman, OK, USA, 73072
\end{abstract}

*Corresponding author's e-mail: sunqiang04@126.com

\begin{tabular}{l}
\hline ARTICLE INFO \\
\hline Article history: \\
Received 16 June 2016 \\
Accepted 23 December 2016 \\
Available online 19 January 2017 \\
\hline
\end{tabular}

Keywords:

Sandstone

Thermal conductivity

Porosity

Grain fabrice

Moisture content

\begin{abstract}
Thermal conductivity is a thermodynamic parameter playing an important role in the heat transfer process in geothermic and numerous engineering fields. In order to analyze the factors influencing the thermal conductivity of sandstone, the data of thermal conductivity obtained from the literatures in China and abroad were summarized. The influences of porosity, moisture and fluidic content, pressure and temperature on the thermal conductivity were analyzed and discussed. The survey results show that the thermal conductivity of sandstones mainly depends on its mineralogical composition, microstructure, porosity, saturation, pressure and temperature. It increases with the degree of fluid saturation and pressure, while decreases with the increase of porosity and temperature. The result of analysis shows that when the degree of saturation is higher than $15 \%$, the thermal conductivity curve is a linear function of the degree of saturation.
\end{abstract}

\section{INTRODUCTION}

Thermal conductivity studies are useful in numerous engineering and scientific applications, e.g. heat containment, thermal rock working, electron beam drilling, simulation of heating and cooling of buildings, weather control, drying of food grains, space technology, aviation, metallurgy, geothermal energy development techniques, etc. (Hofmeister, 2014; Abdulagatov et al., 2015; Verma et al., 2016). To understand the factors influencing the thermal conductivity of rocks is important to analyze and simulate the processes in many geological disasters and the evolution of geological structures, such as rock drilling (Alishaev et al., 2012), rock fragmentation or ore crushing by excavation (Chen et al., 2012; Yang et al., 2015), underground oil or gasification (Tang, 2013), extraction of geothermal energy (Gao, 2015), deep petroleum boring (Sayed, 2011), underground repositories of nuclear wastes (Jan et al., 2009), protection of rock building or rocky cultural relics (Sun et al., 2016), mantle and crustal evolution (Marquardt et al., 2009), earthquake (Marton, 2005), geothermal activity (Chen et al., 2016), magmatic intrusions (Liu et al; 2012), and formation of geological structure (Jana et al., 2012).

In the past few decades, considerable experimental efforts have been taken to quantify the relationship between the thermal conductivity of rock and its influential factors. Intensive studies on the influential factors of the thermal-conductivity of rocks began in the middle 20th century when the geothermal research aimed at evaluating the rate of heat flow (Duchkov et al., 2014). As shown by numerous theoretical studies, the conductivity of rocks depends on various factors (such as, Yang et al., 1986; Liu et al., 2012; and Gao, 2015). These studies have demonstrated the significance of porosity, saturation, pressure, and temperature on rock thermal conductivity, and the complicated relationships between these parameters. For example, Alishaev et al. (2012) and Verma et al. (2016) analyzed the relationships between the porosity, moisture and thermal conductivity, which showed that the thermal conductivity of rocks in general decreases with the porosity, while the increase of moisture content or saturation leads to improved thermal conductivity. Zhao et al. (1995) and Ramazanova and Emirov (2012) measured the thermal conductivity of some typical rocks under different pressure, and the results indicated that significant growth of thermal conductivity with the increase of pressure. The studies of Tang (2013) and Sun et al. (2016) reported that thermal conductivity decreased drastically with elevated temperatures. Clauser and Huenges (1995) reported the relationship between thermal conductivity and the type of mineralogical composition. The mechanisms of thermal conductivity in rocks are so complex that it is difficult and sometimes impossible to theoretically and correctly predict the thermal conductivity of porous materials, even under many simplifications and assumptions (Zarichnyak et al., 2013). Rocks are composed of 
Table 1 Characteristics of the reviewed sandstones.

\begin{tabular}{|c|c|c|c|c|c|c|c|}
\hline Rock type & Ref & Site & $\begin{array}{c}\text { Main } \\
\text { mineralogical } \\
\text { content }\end{array}$ & Test method & $\begin{array}{l}\text { Grain } \\
\text { size }\end{array}$ & $\begin{array}{l}\text { Cementing } \\
\text { quality }\end{array}$ & $\begin{array}{l}\text { Thermal } \\
\text { conductivity } \\
\text { range } / \mathrm{W} \cdot \mathrm{m}^{-1} \cdot \mathrm{K}^{-1}\end{array}$ \\
\hline \multicolumn{8}{|l|}{ Chinese } \\
\hline \multicolumn{8}{|l|}{ Samples: } \\
\hline Sandstone & $\begin{array}{c}\text { Yang et al. } \\
\text { (1986) }\end{array}$ & $\begin{array}{l}\text { Jiyang and } \\
\text { Huanghua }\end{array}$ & $\begin{array}{l}\text { Quartz, Feldspar, } \\
\text { Muscovite }\end{array}$ & $\begin{array}{l}\text { Transient } \\
\text { method }\end{array}$ & $\begin{array}{l}\text { Fine to } \\
\text { Coarse }\end{array}$ & $\begin{array}{l}\text { Calcium, iron, } \\
\text { argillaceous }\end{array}$ & $1.01 \sim 6.20$ \\
\hline Sandstone & $\begin{array}{l}\text { Chen } \\
\text { (1988) }\end{array}$ & $\begin{array}{l}\text { North } \\
\text { China }\end{array}$ & Quartz, Feldspar & $\begin{array}{c}\text { Transient } \\
\text { method }\end{array}$ & - & - & $0.97 \sim 2.57$ \\
\hline $\begin{array}{l}\text { Calcareous } \\
\text { sandtone }\end{array}$ & $\begin{array}{c}\text { Zhao et al. } \\
\text { (1995) }\end{array}$ & - & - & $\begin{array}{l}\text { Loop heating } \\
\text { source method }\end{array}$ & - & - & $1.01 \sim 6.20$ \\
\hline $\begin{array}{l}\text { Feldspathic } \\
\text { quartz } \\
\text { sandstone }\end{array}$ & $\begin{array}{l}\text { Zhao et al. } \\
\text { (1995) }\end{array}$ & - & Quartz, Feldspar & $\begin{array}{c}\text { Transient } \\
\text { method }\end{array}$ & - & - & $2.67 \sim 4.75$ \\
\hline Sandstone & Li (2009) & $\begin{array}{l}\text { Shengli } \\
\text { oilfield }\end{array}$ & - & - & - & - & $1.0 \sim 2.92$ \\
\hline Sandstone & Gao (2015) & Ordos basin & Quartz, Feldspar & $\begin{array}{c}\text { Transient } \\
\text { method (TCS) }\end{array}$ & - & - & $2.02 \sim 4.03$ \\
\hline sandstone & $\begin{array}{l}\text { Tang } \\
(2013)\end{array}$ & $\begin{array}{l}\text { Ulangab } \\
\text { Coal mine }\end{array}$ & - & $\begin{array}{c}\text { Transient } \\
\text { method (DRX) }\end{array}$ & - & - & $0.90 \sim 1.41$ \\
\hline $\begin{array}{l}\text { Fine } \\
\text { sandstone }\end{array}$ & $\begin{array}{l}\text { Tang } \\
(2013)\end{array}$ & $\begin{array}{l}\text { Ulangab } \\
\text { Coal mine }\end{array}$ & Fine & $\begin{array}{c}\text { Transient } \\
\text { method (DRX) }\end{array}$ & - & - & $1.20 \sim 0.90$ \\
\hline $\begin{array}{l}\text { Coarse } \\
\text { sandstone }\end{array}$ & $\begin{array}{l}\text { Tang } \\
\text { (2013) }\end{array}$ & $\begin{array}{l}\text { Ulangab } \\
\text { Coal mine }\end{array}$ & Coarse & $\begin{array}{l}\text { Transient } \\
\text { method (DRX) }\end{array}$ & - & - & $0.81 \sim 1.30$ \\
\hline Sandstone & $\begin{array}{l}\text { Sun et al. } \\
\text { (2016) }\end{array}$ & Linyi & $\begin{array}{c}\text { Quartz, Feldspar, } \\
\text { Dolomite }\end{array}$ & Fine & Fine & Calcium, iron & $0.71 \sim 2.32$ \\
\hline \multicolumn{8}{|l|}{$\begin{array}{l}\text { Samples } \\
\text { from other } \\
\text { countries: }\end{array}$} \\
\hline Sandstone & $\begin{array}{l}\text { Maqsood } \\
\text { and } \\
\text { Kamran } \\
(2005)\end{array}$ & $\begin{array}{l}\text { Khewra, } \\
\text { Pakistan }\end{array}$ & $\begin{array}{l}\text { Quartz, } \\
\text { Feldspars, } \\
\text { Calcite, } \\
\text { Dolomite }\end{array}$ & $\begin{array}{c}\text { Transient } \\
\text { method (TPS) }\end{array}$ & Fine & - & $2.82 \sim 4.2$ \\
\hline Sandstone & $\begin{array}{l}\text { Duchkov et } \\
\text { al. (2014) }\end{array}$ & $\begin{array}{l}\text { Siberian, } \\
\text { Russia }\end{array}$ & - & $\begin{array}{c}\text { Transient } \\
\text { method }\end{array}$ & - & - & $0.6 \sim 3.2$ \\
\hline Sandstone & $\begin{array}{c}\text { El Sayed } \\
(2011)\end{array}$ & $\begin{array}{l}\text { Szolnok, } \\
\text { Hungary }\end{array}$ & - & $\begin{array}{c}\text { Transient } \\
\text { method (TCS) }\end{array}$ & - & - & $1.01 \sim 4.37$ \\
\hline Sandstone & $\begin{array}{l}\text { Zarichnyak } \\
\text { et al. (2013) }\end{array}$ & $\begin{array}{c}\text { Dagestan, } \\
\text { Russia }\end{array}$ & - & - & Fine & - & $1.66 \sim 2.55$ \\
\hline Sandstone & $\begin{array}{l}\text { Alishaev et } \\
\text { al (2012) }\end{array}$ & $\begin{array}{l}\text { Dagestan, } \\
\text { Russia }\end{array}$ & - & $\begin{array}{l}\text { Seady state } \\
\text { method }\end{array}$ & Moderate & - & $2.34 \sim 3.81$ \\
\hline Sandstone & $\begin{array}{l}\text { Nagaraju } \\
\text { and } \\
\text { Sukanta }\end{array}$ & $\begin{array}{l}\text { North } \\
\text { central } \\
\text { India }\end{array}$ & - & $\begin{array}{l}\text { Seady state } \\
\text { method }\end{array}$ & - & - & $3.3 \sim 6.62$ \\
\hline
\end{tabular}

mineral particles with various chemical compositions and different degrees of crystallization. Therefore, the thermal conductivity of rocks depend not only on the pressure and temperature but also on their mineralogical compositions, the structure and geometry of pores, grain size, crack shape, and their concentration (Nabawy and Géraud, 2016).

Sandstone is a common sedimentary rock, having broad applications in geotechnical engineering (Tian et al., 2012). Therefore, research on the factors influencing the thermal conductivity of sandstone is extremely meaningful. In this study, some factors, such as porosity, saturation (or moisture content), pressure, and temperature of sandstone, are considered.

\section{DATA SOURCES}

The data set was taken from a number of authors (as listed in Table 1). Table 1 lists the detailed information about the acquisition of data used in analysis, including the rock type, literature source, sampling location, main minerals and grain size. The data were carefully selected taking into account the following conditions:

1. Original measurement data without smoothing or any other data processing.

2. Only the data for sandstone, siltstone and sandy mudstone.

3. Data from a sufficiently wide range of temperature, porosity, and pressure and from four or more measuring points were selected.

Under these conditions the applicable data in the published literature is further reduced. One has to keep in mind that it is a great venture to compare results from various sources obtained with quite different measuring methods and often of unknown accuracy (Seipold, 1998). The test methods of rock thermal conductivity are mainly divided into two 
kinds, i.e. the steady-state measurement and the transient methods. The steady-state method has a higher precision; however, it requires excessively long hours and has highly strict requirements for sample preparation. Sometimes, it is not convenient to test. Klute (1986) indicated that the main advantages of the transient methods were: (1) the moisture migration in response to temperature gradients was minimized and (2) a shorter wait time for the thermal gradient to equilibrate than in the steady-state method, so the transient methods are more precise and convenient techniques for testing thermal transport properties.

\section{ANALYSIS AND DISCUSSION}

\subsection{INFLUENCE OF POROSITY, MOISTURE AND FLUID CONTENT ON THERMAL CONDUCTIVITY}

Sandstone is a kind of porous material, and most have pores of primary or secondary origin. The porosity of sandstone sometimes can be up to $40 \%$ (Nabawy and Géraud, 2016). It has an important influence on the thermal conductivity of rock. As shown in Figure1, the thermal conductivity changes significantly with the increase of porosity. The thermal conductivity of dry sedimentary rocks is mainly determined by the porosity. They are usually in inverse correlation, which is stronger if the thermal conductivity and porosity are obtained from the same samples. The effect of the mineral composition of dry rocks on their thermal conductivity is minor (Duchkov et al., 2014). The thermal conductivity under the saturated condition is larger than the dry condition because the thermal conductivity of saline is higher than that of the air (Nabawy and Géraud, 2016).

There is a reciprocal relationship between the thermal conductivity and porosity under the dry and saturated conditions as shown in Eq. (1) and Eq. (2), respectively and in Figure 1. Comparison between the results under the dry and saturated conditions show that the correlation between the thermal conductivity and porosity for water-saturated sandstones is much weaker than those under the dry condition, because the orientation of the pore and grain fabrics are different and not aligned parallel (Nabawy and Géraud, 2016).

$$
\begin{array}{ll}
K_{d}=\frac{1}{0.295+0.018 \varnothing}, \quad R^{2}=0.539 \\
K_{w}=\frac{1}{0.251+0.010 \varnothing}, \quad R^{2}=0.420
\end{array}
$$

where $\varnothing$ is the porosity (\%), and $K_{d}$ and $K_{w}$ are the thermal conductivity under the dry and saturated conditions, respectively $\left(\mathrm{W} \cdot \mathrm{m}^{-1} \cdot \mathrm{K}^{-1}\right)$.

The plots of the ratio of thermal conductivity under the dry and saturated conditions is demonstrated such as function of porosity (Eq. (3) and (Fig. 2a). There is a good linear relationship between $K_{w} / K_{d}$ and $\varnothing$. Figure 2 (b) shows the relation between the thermal conductivities under the dry

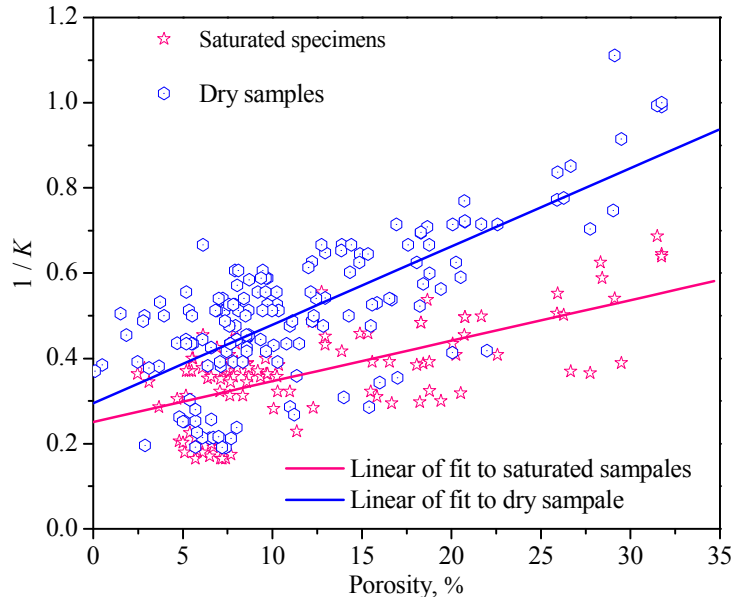

Fig. 1 Relations of thermal conductivity and porosity under dry and saturated conditions (number of dry and saturated samples are 158 and 108 , respectively).

condition and saturated condition (shown in Eq. (4)). Direct juxtaposition of $K_{w}$ and $K_{d}$ shows a strong positive correlation between them:

$$
\begin{aligned}
& K_{w} / K_{d}=1.092+0.025 \varnothing, \quad R^{2}=0.534 \\
& K_{w}=0.696+1.033 K_{d}, \quad R^{2}=0.897
\end{aligned}
$$

The thermal conductivities of Ordos sandstone has a linear relationship with the moisture content (Fig. 3), as described by Eq. (5):

$$
K=2.147+0.385 w, \quad R^{2}=0.769
$$

where $w$ is the moisture content $(\%)$, and $K$ is the thermal conductivity of sandstone $\left(\mathrm{W} \cdot \mathrm{m}^{-1} \cdot \mathrm{K}^{-1}\right)$.

The thermal conductivities of sandstones may have a linear relationship with the degree of saturation (Fig. 4a). Although one can get that from Figure 4b, at the same degree of saturation, the thermal conductivity of a rock - oil - water system is greater than the thermal conductivity of a rock - gas - water system.

\subsection{INFLUENCE OF PRESSURE ON THERMAL CONDUCTIVITY}

In the range of 0.1 to $22 \mathrm{MPa}$, the thermal conductivity of rocks has a significant trend of linear increase with pressure (Fig. 5). However, it increases nonlinearly under the action of pressure (as shown in Fig. 6), and increases more substantially at pressures below $100 \mathrm{MPa}$, before the occurrence of a smooth transition to saturation. At pressure less than $400 \mathrm{MPa}$, the increase is $15-18 \%$ in the sample saturated with oil, and the change of pressure in the same range causes an increase of the thermal conductivity of water saturated samples only by 8$10 \%$. The pressure also influences the temperature dependence of thermal conductivity. As illustrated in Figure 6, the increases of the thermal conductivity of samples saturated with oil and those saturated with water are about 5-7 \% and 11-15\%, respectively. 


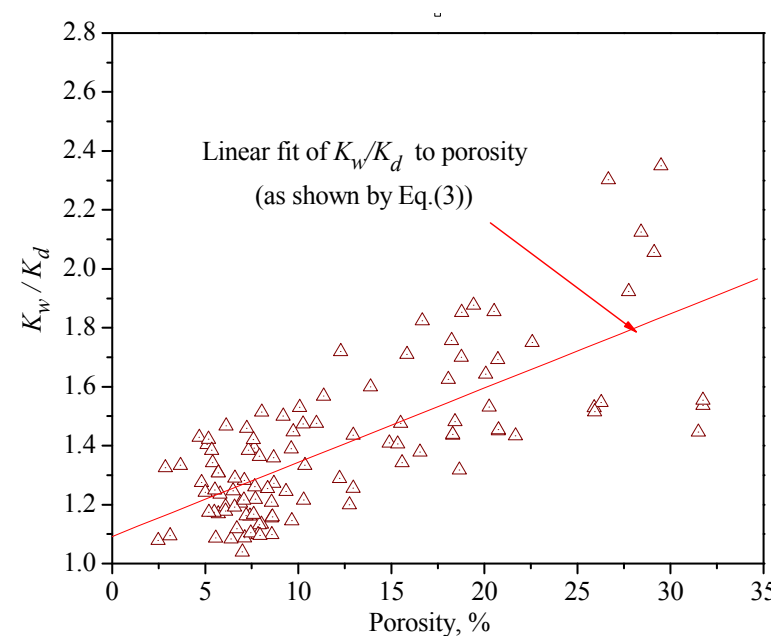

(a)

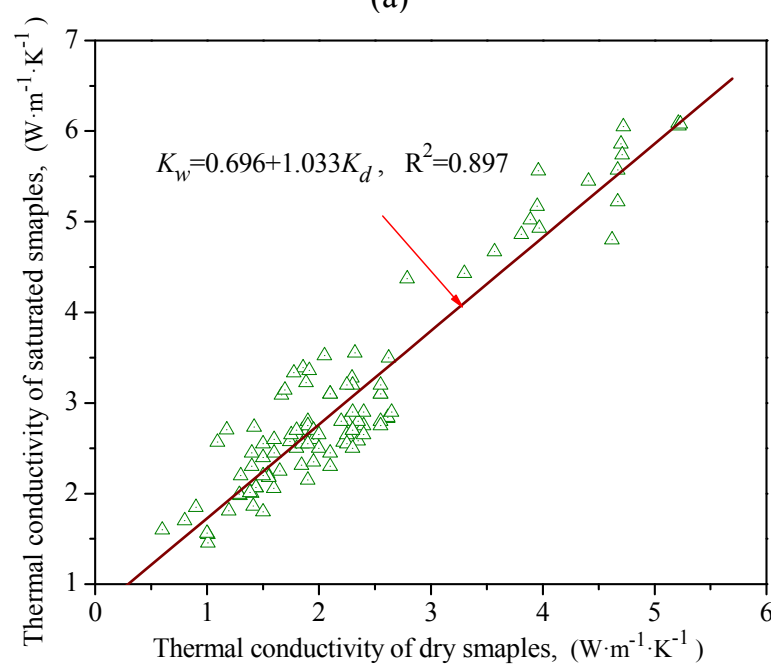

(b)

Fig. 2 Relations of thermal conductivity for dry and saturated samples and the influence of porosity (number of samples is 108).

(a) Relation between porosity and ratio of thermal conductivity of dry condition to saturated condition; (b) Linear correlation between the measured thermal conductivities under dry and water-saturated samples.

The increase of thermal conductivity with the increase of pressure substantially depends on the thermal conductivity of the fluid filled in the pores (Zarichnyak et al., 2013).

\subsection{INFLUENCE OF TEMPERATURE ON THERMAL CONDUCTIVITY}

Temperature plays an important role among the various factors influencing the thermal conductivity of rocks. In the range of room temperature up to $1000 \mathrm{C}$, the thermal conductivity of rocks has a significant nonlinear decrease (Fig. 7), which can be described by the following equations:

$$
K=\frac{1}{0.427+7.889 \times 10^{-4} T}, \quad R^{2}=0.644
$$

where $T$ is the temperature $\left({ }^{\circ} \mathrm{C}\right)$, and $K$ is the thermal conductivity $\left(\mathrm{W} \cdot \mathrm{m}^{-1} \cdot \mathrm{K}^{-1}\right)$.

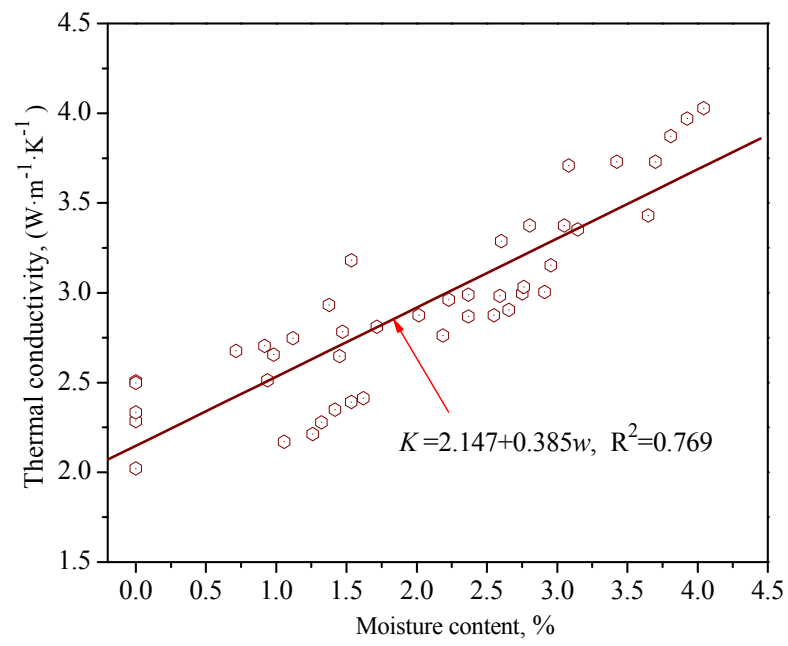

Fig. 3 The variation of thermal conductivity versus moisture content (Data imported from Gao (2015)).

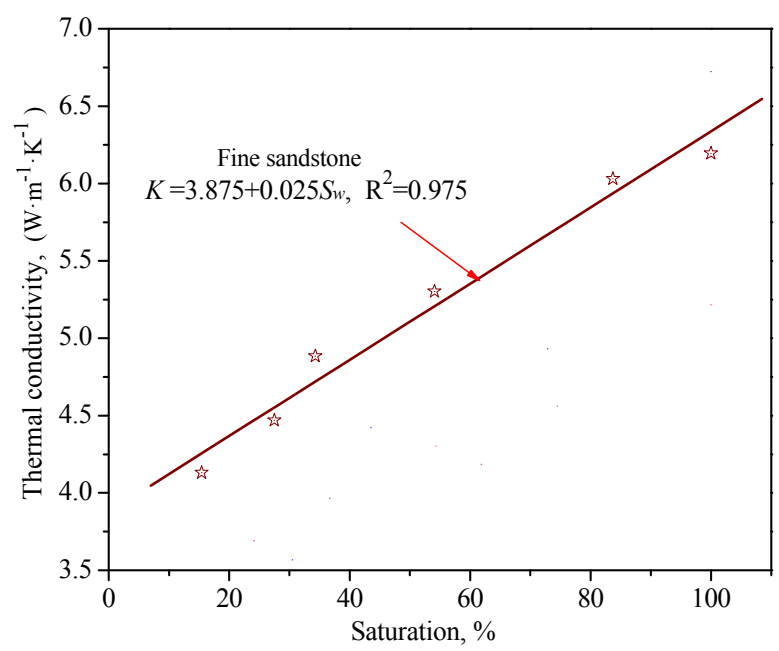

(a)

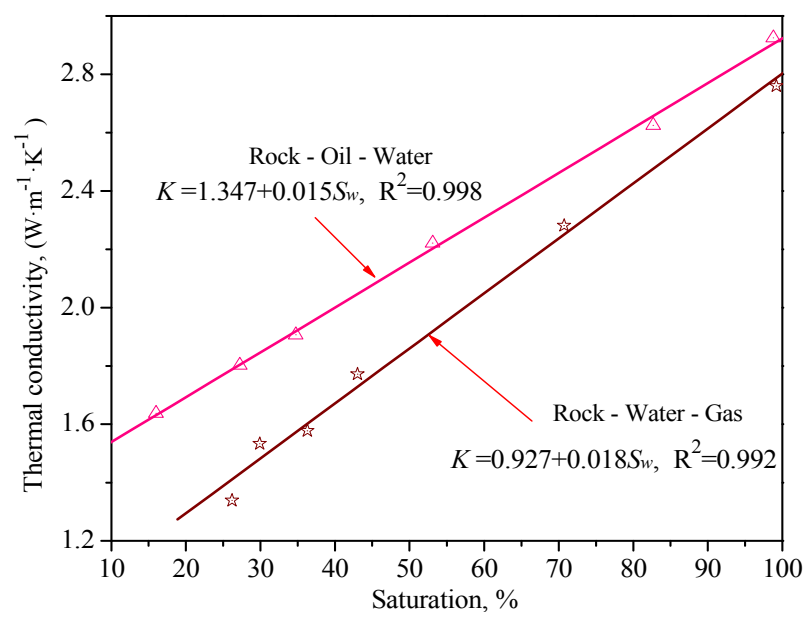

(b)

Fig. 4 Relations of thermal conductivity and saturation. (a) Relation between thermal conductivity and saturation (Data imported from Yang et al., 1986); (b) Linear correlation between the measured thermal conductivities and saturation (Data imported from Li (2009)). 


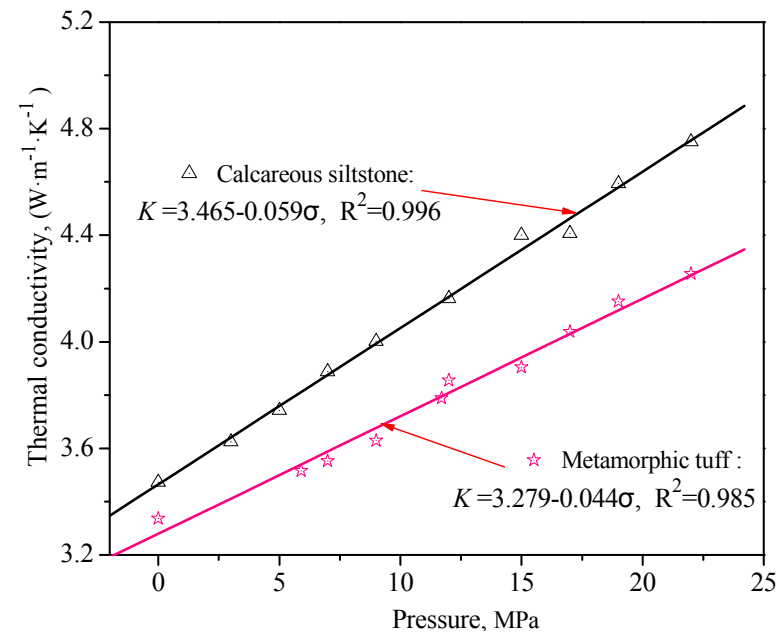

Fig. 5 Relations of thermal conductivity and pressure (Data from Zhao et al. (1995)).

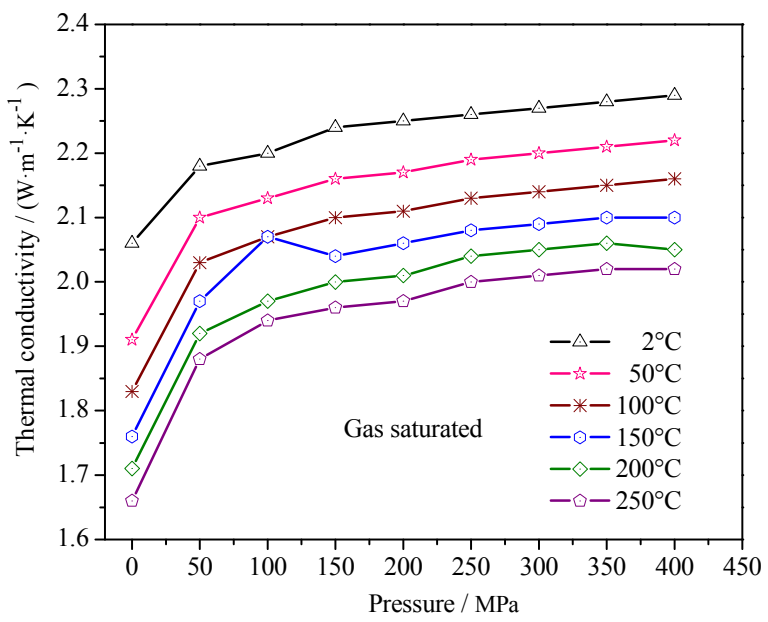

(a)

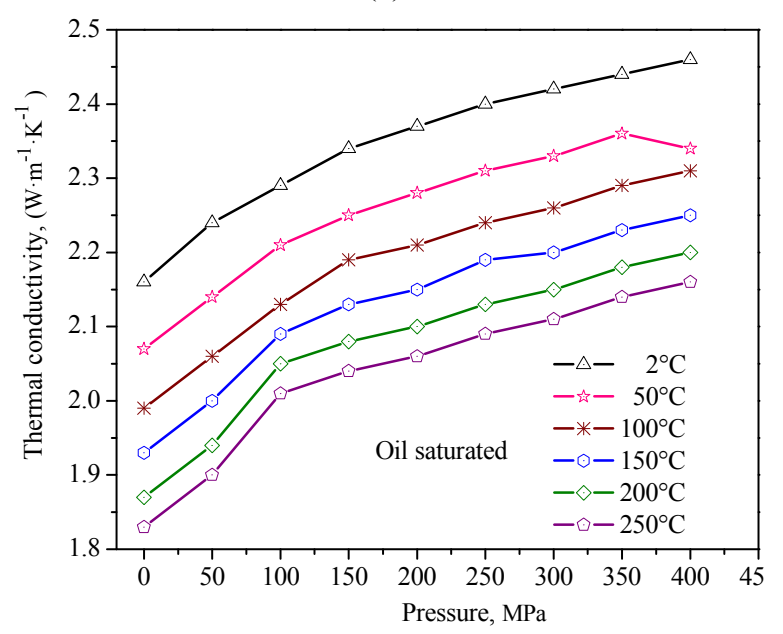

(c)
In Figure 7, it is shown that the thermal conductivity decreases more quickly with temperature in the range from the room temperature to $400^{\circ} \mathrm{C}$, and then a smooth transition to temperature is observed. Figure 8 shows a similar pattern when the pores are filled by gas, water or oil.

\subsection{DISCUSSIONS}

Rocks are a mixture of anisotropic crystals of different compositions, which leads to relatively small change in the thermal conductivity (Fig. 9) other than the lattice thermal conductivity and in some cases the thermal conductivity varies with temperature and pressure (Somerton, 1992; Zarichnyak et al., 2013; Verma et al., 2016). The thermal conductivity of sandstone is determined not only by their mineral composition but also by their grain and pore fabrics: porosity, dispersion, roundness and grain sorting, type of cementing material, and type of fluid filling in the pores. This explains the scattered points in the correlation field. The pressure and temperature influence the thermal conductivity of rocks by changing their pore and grain fabrics.

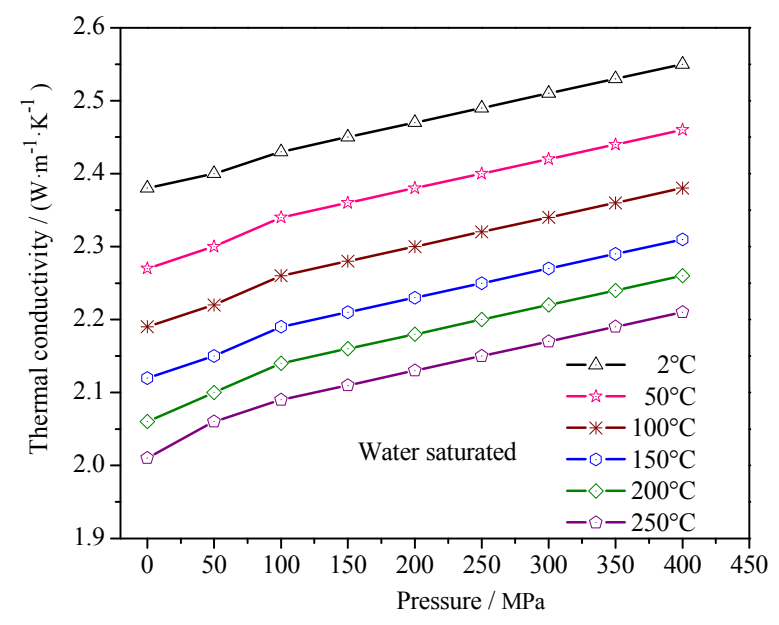

(b)

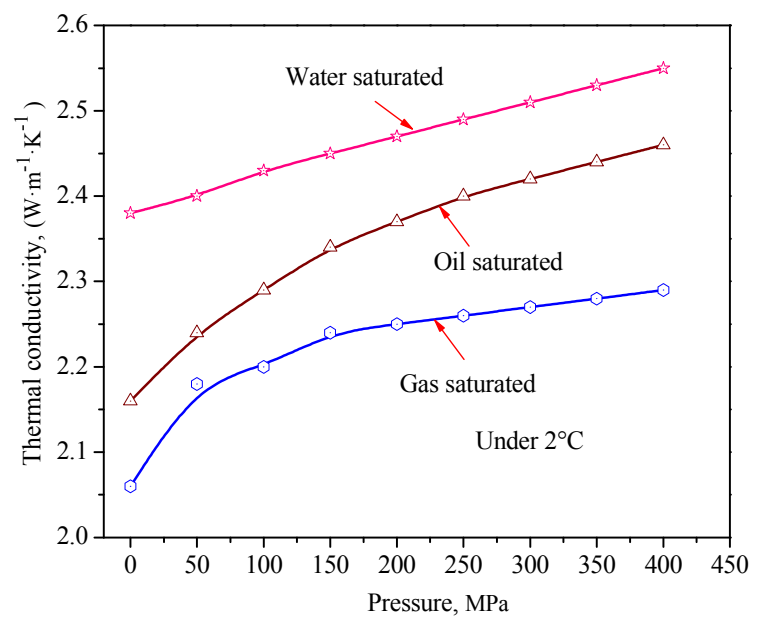

(d)

Fig. 6 Relations of thermal conductivity and pressure under different temperature (Data imported from Emirov and Ramazanova, 2012). (a) Gas in pores; (b) Water in pores; (c) Oil in pores; (d) Gas, water, oil in pores, respectively, under $2{ }^{\circ} \mathrm{C}$. 


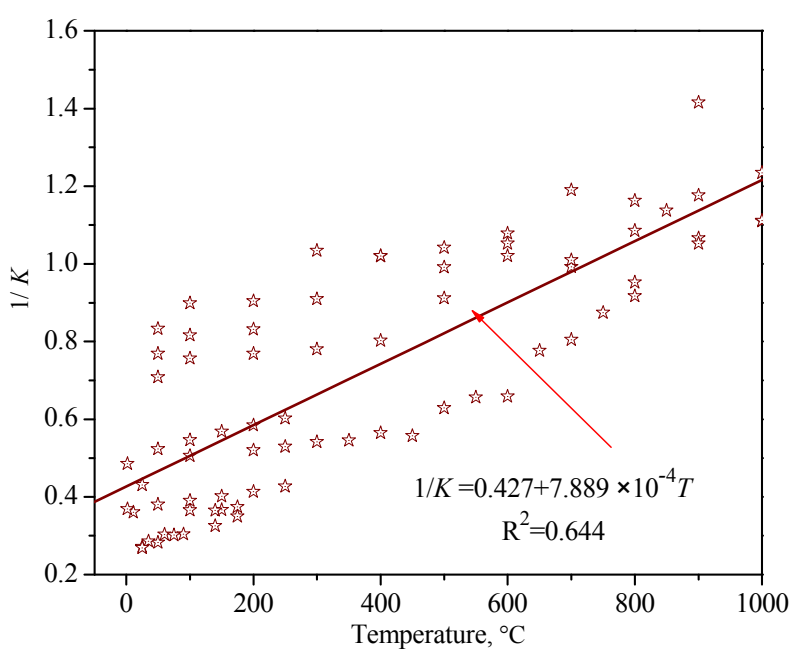

Fig. 7 Relations of thermal conductivity and temperature (The number of test points is 76).

These changes of thermal conductivity can be analyzed according to the theory of classical physics (Maqsood et al., 2003; Shabbir et al., 2000). This theory regards the heat conduction inside solid materials as a result of the diffusion movement of phonons, or, the elastic vibration of lattice. The thermal conductivity of rocks, $K$, can be approximated by (Tang et al., 2013):

$$
K=\frac{1}{3} c_{v} \bar{l} v_{0}
$$

where $c_{v}$ is the heat capacity per unit volume; $\bar{l}$ is the mean free path for phonons; $v_{0}$ denotes the energy transport velocity of phonon and is usually simplified as the normal sound velocity. The mean free path of phonons is directly related to two processes: the collisions of phonons and the scattering of phonon impurity (crystal imperfection).

From Eq. (7), it can be obtained that with the increase of porosity, the crystal imperfection is growing, which means that the free path of phonons decreases. Moreover, at low saturation degrees, most pores or cracks are filled with the air. Thus, the thermal conductivity is reduced with the increase of porosity. However, the thermal conductivity of water is about 32 times of that of the air (Yang et al., 1986). Therefore, the thermal conductivity of saturated rock is larger than that of the dry rock. With the increase of saturation, the thermal conductivity of rock has a quick nonlinear increase. However, when the degree of saturation reaches some level (maybe $15 \%$ ), the rate of inrease becomes constant. Hence, there is a linear increase in the thermal conductivity with the degree of saturation. It can also explain the increase of thermal conductivity with pressure. As we know, sandstone consists of a mixture of rock forming minerals with high quartz content, hence a high thermal conductivity. With the increase of pressure, pores or microcracks between the skeleton of rocks are compressed, while the microscopic structure of pore spaces becomes closed, contributing to the increase of thermal conductivity. The effect of pressure on the thermal conductivity is, more

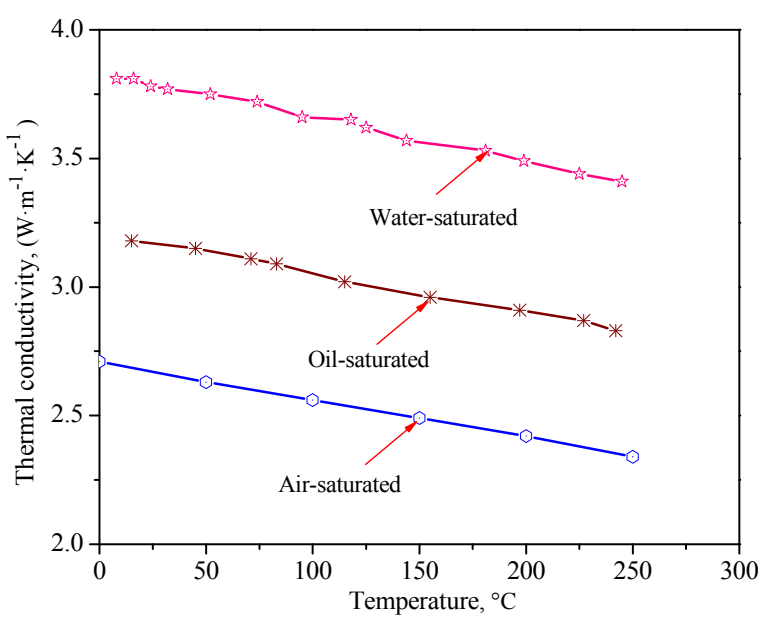

(a)

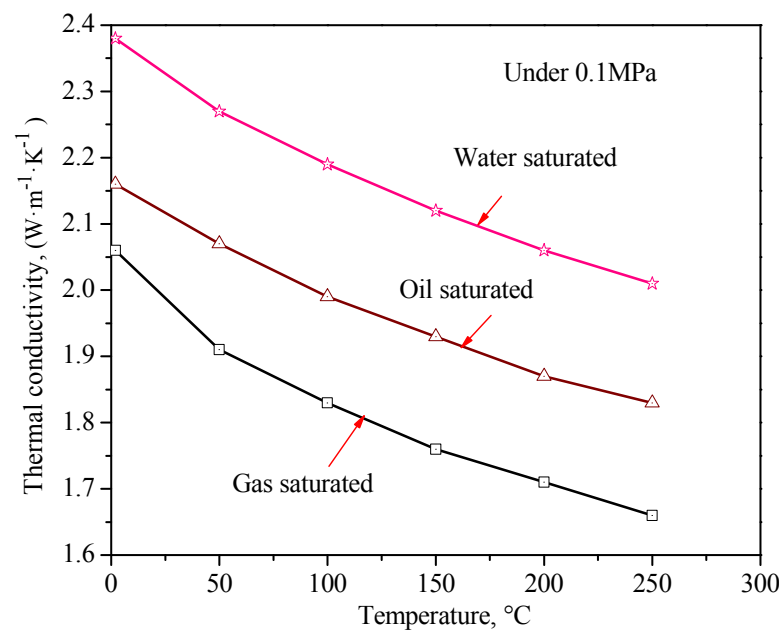

(b)

Fig. 8 Relations of thermal conductivity and temperature for sandstone. (a) Data imported from Alishaev et al. (2012); (b) Data imported from Emirov and Ramazanova (2012).

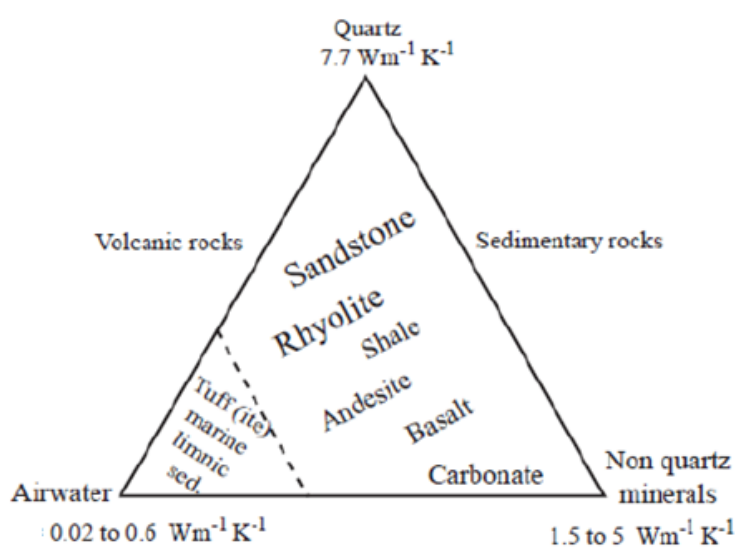

Fig. 9 Thermal conductivity of rock forming minerals and relation of composition with rock type volcanic and sedimentary (Clauser and Huenges, 1995). Third mineral phase for volcanic and sedimentary rocks is air or water, for thermal conductivity of these rocks, porosity is important property. 
significant for the rocks with loose structure when compared with the dense rocks.

At high temperatures, the average number of phonons in a rock is proportional to the temperature. With the increase of temperature, the probability of the collision of phonons increases and thus the mean free path of phonons decreases. The temperature dependence of the mean free path available for photons is given by (Tang et al., 2013)

$\bar{l}=\frac{1}{\sqrt{2} \sigma \bar{n}} \approx \frac{h \bar{w}}{\sqrt{2} \sigma k T}$

where $\sigma$ is the effective collision cross section; $\bar{n}$ is the average number of phonons and $\bar{n} \approx k T / h \bar{w} ; k$ is the Boltzmann constant; $h$ is the Plank constant; and $\bar{w}$ is the frequency of phonons. In the solid state physics, the composition of a solid material is assumed to be independent of the temperature and the heat capacity as well. As a result, the thermal conductivity $K$ is inversely proportional to the temperature, as shown in Eq. (9), and it can also explain the variation of thermal conductivity in Figure 7.

$1 / K \propto T$

When the applied temperature is higher than $400{ }^{\circ} \mathrm{C}$ (especially higher than $600{ }^{\circ} \mathrm{C}$ ), the physical and chemical features of sandstone minerals would change. Between $400{ }^{\circ} \mathrm{C}$ and $600{ }^{\circ} \mathrm{C}$, the minerals of rocks have chemical changes. The most remarkable reaction is the inversion of quartz from the $\alpha$ - to the $\beta$ phase at $573^{\circ} \mathrm{C}$ (Sun et al., 2016). Somerton and Selim (1961) measured the thermal volume expansion and the heat of reaction for three typical sandstones (Fig. 10a). In their test, the expansion of quartz and sandstone were tested at a rising rate of $6.0{ }^{\circ} \mathrm{C} / \mathrm{min}$. The quartz content of the Boise sandstone and the Berea sandstone are $50 \%$ and $90 \%$, respectively. They reported that the permanent deformation and structural damage to the tested samples after heating lead to a change in the thermal conductivity of heated sandstone samples. It was also proposed that, when the temperature is higher than $400{ }^{\circ} \mathrm{C}$, quartz has a nonlinear thermal volume expansion, which can be used to explain the variation of thermal conductivity (Fig. 10b).

\section{CONCLUSION}

An extensive review and analysis were conducted based on the data in international and Chinese publications. The results are expected to benefit researchers and engineers involved in analytical and numerical modeling of thermal conductivity involved processes in sandstones. The following conclusions could be drawn:

1. Thermal conductivity of sandstones mainly depends on the mineral composition, microstructure, porosity, saturation, pressure and temperature. Thermal conductivity increases with the increase of fluid saturation and pressure, but is reduced with the increase of porosity and temperature.

2. There is a linear relationship between the thermal conductivity of sandstone and the moisture content, or the degree saturation, and a reciprocal relationship between the thermal conductivity and porosity, and also a reciprocal relationship between the thermal conductivity and temperature. However, with the increases of pressure, the thermal conductivity increases gradually, and the rate of increase below $100 \mathrm{MPa}$ is larger than that in $100-400 \mathrm{MPa}$.

\section{ACKNOWLEDGMENTS}

This research was supported by "the Fundamental Research Funds for the Central Universities" (No.2015XKMS033) and the Priority Academic Program Development of Jiangsu Higher Education Institutions.

\section{REFERENCES}

Abdulagatov, I.M., Abdulagatova, Z.Z., Kallaev, S.N., Bakmaev, A.G. and Ranjith, P.G.: 2015, Thermaldiffusivity and heat-capacity measurements of sandstone at high temperatures using laser flash and DSC methods. Int. J. Thermophys., 36, 658-691. DOI: $10.1007 / \mathrm{s} 10765-014-1829-4$

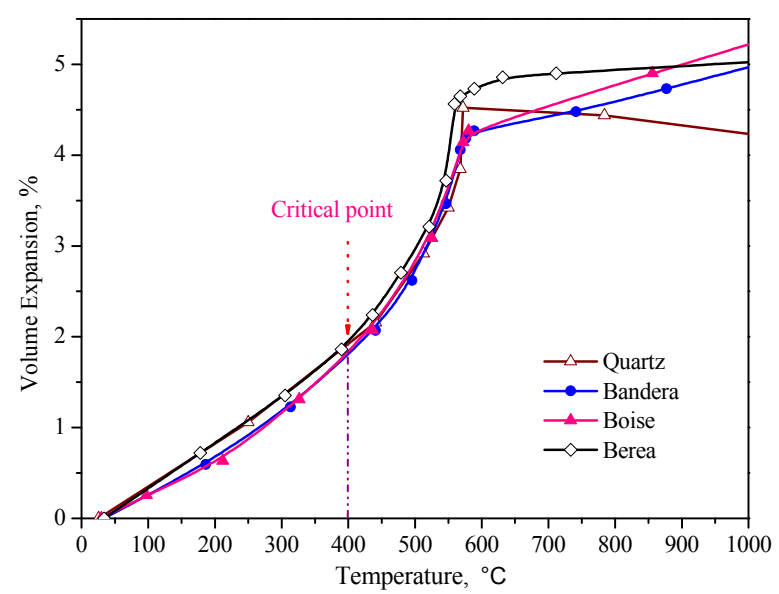

(a)

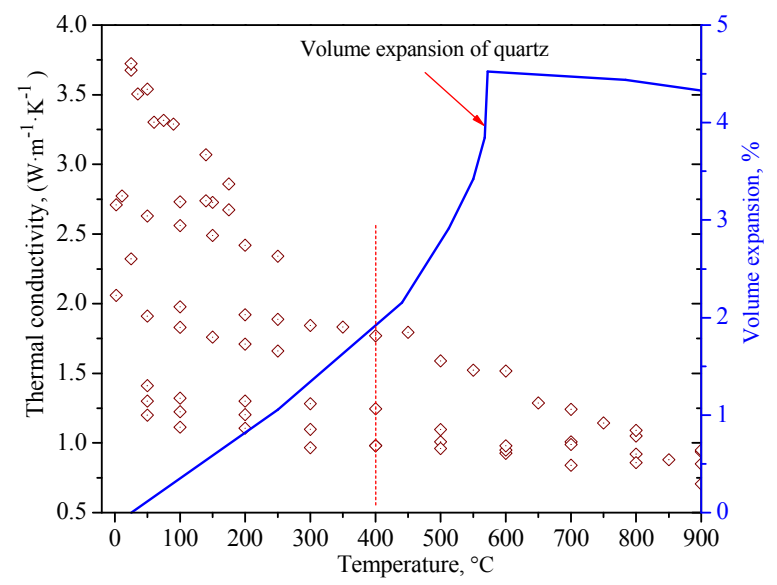

(b)

Fig. 10 Variations of thermal conductivity and volume expansion of quartz with temperature. (a) Volume expansion of quartz and sandstone (Data imported from Somerton and Selim (1961)); (b) Volume expansion of quartz and variation of thermal conductivity with increasing temperature. 
Alishaev, M.G., Abdulagatov, I.M. and Abdulagatova, Z.Z.: 2012, Effective thermal conductivity of fluid-saturated rocks: Experiment and modeling. Eng. Geol., 135, 2439. DOI: $10.1016 /$ j.enggeo.2012.03.001

Chen, Y.F., Li, D.Q., Jiang, Q.H. and Zhou, C.B.: 2012, Micromechanical analysis of anisotropic damage and its influence on effective thermal conductivity in brittle rocks. Int. J. Rock Mech. Min. Sci., 50, 102116. DOI: $10.1016 /$ j.ijrmms.2011.11.003

Clauser, C. and Huenges, E.: 1995: Thermal conductivity of rocks and minerals. In: Ahrens, T.J. (ed),Rock physics and phase relations. American Geophysical Union, Washington, D.C, 105-126.

Duchkov, A.D., Sokolova, L.S., Rodyakin, S.V. and Chernysh, P.S.: 2014, Thermal conductivity of the sedimentary-cover rocks of the West Siberian Plate in relation to their humidity and porosity. Russ. Geol. Geophys., 55, 784-792.

DOI: $10.1016 /$ j.rgg.2014.05.021

Gao, P.: 2015, Analysis of rock thermal physical parameters and research on multi-field thermal effect coupled model. Changchun: Doctor. Thesis, Jilin University.

Emirov, S.N. and Ramazanova, A.E.: 2012, Baric and temperature dependences for the thermal conductivity of sedimentary rocks. Bull. Russ. Acad. Sci. Phys., 76(10), 1152-1156. DOI: $10.3103 / \mathrm{S} 1062873812100103$

Hofmeister, A.M.: 2014, Thermal diffusivity and thermal conductivity of single-crystal $\mathrm{MgO}$ and $\mathrm{Al}_{2} \mathrm{O}_{3}$ and related compounds as a function of temperature. Phys. Chem. Minerals, 41, 361-371. DOI: $10.1007 / \mathrm{s} 00269-014-0655-3$

Jana, J. and Agnes, K.: 2012, Thermally induced alterations of minerals during measurements of the temperature dependence of magnetic susceptibility: a case study from the hydrothermally altered Soultz-sous-Forêts granite, France. Int. J. Earth Sci., 101, 819-839. DOI: $10.1007 / \mathrm{s} 00531-011-0668-9$

Klute, A.: 1986, Physical and mineralogical methods. American Soc. of Agronomy (Second Edition) [u.a.], Madison, Wisc.

Liu, S.Q., Li, Y.B., Tian, H.Q., Liu, X.Y., Zhu, B.J. and Shi, Y.L.: 2012, Numerical simulation on thernal conductivity of wet porous rock. Chin. J. Geophys., 55(12), 4239-4248. DOI: $10.6038 /$ j.issn.0001-5733.2012.12.035

Li, J.S.: 2009, Testing and analysis of thermal properties of reservoir rocks. J. Daqing Petrol. Inst., 33 (5), 23-26.

Maqsood, A. and Kamran, K.: 2005, Thermophysical properties of porous sandstones: measurements and comparative study of some representative thermal conductivity models. Int. J. Thermophys., 26(5), 1617-1632. DOI: $10.1007 / \mathrm{s} 10765-005-8108-3$

Maqsood, A., Rehman, M.A. and Gul, I.H.: 2003, Chemical composition, density, specific gravity, apparent porosity, and thermal transport properties of volcanic rocks in the temperature range 253 to $333 \mathrm{~K}$. J. Chem. Eng. Data., 48, 1310-1314. DOI: 10.1021/je034077p

Miao, S.Q., Li, H.P. and Chen, G.: 2014, Temperature dependence of thermal diffusivity, specific heat capacity, and thermal conductivity for several types of rocks. J. Therm. Anal. Calorim., 115, 1057-1063. DOI: 10.1007/s10973-013-3427-2

Nabawy, B.S. and Géraud, Y.: 2016, Impacts of pore- and petro-fabrics, mineral composition and diagenetic history on the bulk thermal conductivity of sandstones. J. Afr. Earth Sci., 115, 48-62. DOI: $10.1016 /$ j.jafrearsci.2015.11.025
Nagaraju, P. and Sukanta R.: 2014, Effect of water saturation on rock thermal conductivity measurements. Tectonphysics, 626, 137-143. DOI: $10.1016 /$ j.tecto.2014.04.007

Robertson, E.C. and Peck, D.L.: 1974, Thermal condutivity of vesicular basalt from Hawaii. J. Geophys. Res., 79(32), 4875-4888. DOI: 10.1029/JB079i032p04875

Seipold, U.: 1998, Temperature dependence of thermal transport properties of crystalline rocks-a general law. Tectonphysics., 291, 161-171. DOI: $10.1016 / \mathrm{S} 0040-1951(98) 00037-7$

Shabbir, G., Maqsood, A. and Majid, C.A.: 2000, Thermophysical properties of consolidated porous rocks. J. Phys. D-Appl. Phys., 33, 658-661. DOI: $10.1088 / 0022-3727 / 33 / 6 / 311$

Somerton, W.H.: 1992, Thermal properties and temperature related behavior of rock/fluid system. Elsevier, Amsterdam.

Somerton, W.H. and Selim, M.S.: 1961, Additional thermal data for porous rocks - Thermal expansion and heat of reaction. Soc. Petrol. Eng. J., 4, 249-253.

DOI: $10.2118 / 1613-G$

Somerton, W.H. and Boozer, G.D.: 1960, Thermal characteristics of porous rocks at elevated temperatures. J. Pet. Tech., 12(6), 77-81.

DOI: $10.2118 / 1372-\mathrm{G}$

Sayed, A.M.A.E.: 2011, Thermophysical study of sandstone reservoir rocks. J. Petrol. Sci. Eng., 76(3-4), 138-147. DOI: 10.1016/j.petrol.2011.01.001

Sun, Q., Lu, C., Cao, L.W., Li, W.C., Geng, J.S. and Zhang, W.Q.: 2016, Thermal properties of sandstone after treatment at high temperature. Int. J. Rock Mech. Min. Sci., 85, 60-66. DOI: 10.1016/j.ijrmms.2016.03.006

Tang, F.R.: 2013, Fracture evolution and breakage of overlying strata of combustion space area in underground coal gasification. Xuzhou: Doctor. Thesis, China University of Ming \& Technology.

Tian, H., Kempka, T., Xu, N.X. and Ziegler, M.: 2012, Physical properties of sandstones after temperature treatment. Rock Mech. Rock Eng., 45, 1113-1117. DOI: $10.1007 / \mathrm{s} 00603-012-0228-\mathrm{Z}$

Verma, A.K., Jha, M.K., Maheshwar, S., Singh, T.N. and Bajpai, R.K.: 2016, Temperature-dependent thermosphysical properties of Ganurgarh shales from Bhander group, India. Environ. Earth Sci., 75. DOI $10.1007 / \mathrm{s} 12665-015-4992-4$

Vosteen, H.D. and Schellschmidt, R.: 2003, Influence of temperature on thermal conductivity, thermal capacity and thermal diffusivity for different types of rock. Phys. Chem. Earth, 28, 499-509. DOI: $10.1016 / \mathrm{S} 1474-7065(03) / 00069-\mathrm{X}$

Yang, G.S., Yuan, Y.Z., Shen, Y.J. and Qu, Y.L.: 2015, Analysis on thermal conductivity of cretaceous sandstone associated with microstructure. Coal Eng., 47 (9), 82-85.

Yang, S.Z., Zhang, W.R. and Shen, X.J.: 1986, Experimental research on the thermal conductibity of watwe-saturated porous rocks. Acta Petrologica Sinica, 2(4), 83-91.

Zarichnyak, Y.P., Emirov, S.N. and Ramazanova, A.E.: 2013, Contribution of thermal radiation in measurements of thermal conductivity of sandstone. Phys. Solid State, 55(12), 2463-2441.

Zhao, Y.X., Yang, S.Z., Zhang, W.R., Liang, X.R. and Ma, L.Y.: 1995, An experimental study of rock thermal conductivity under different temperature and pressure. Prog. Geophys., 10(1), 104-113. 